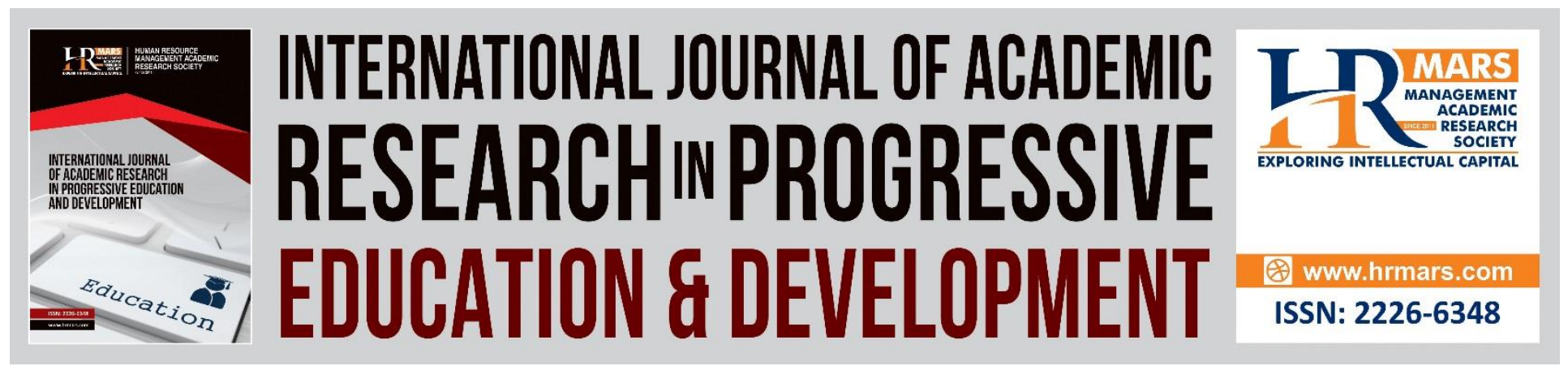

\title{
Factors Influencing Student Satisfaction towards Distance Learning Apps During the Coronavirus (Covid-19) Pandemic in Malaysia
}

Md Wasiul Karim, Ahasanul Haque, Mohammad Arije Ulfy, Md Suliman Hossin

To Link this Article: http://dx.doi.org/10.6007/IJARPED/v10-i2/9546

DOI:10.6007/IJARPED/v10-i2/9546

Received: 09 February 2021, Revised: 12 March 2021, Accepted: 06 April 2021

Published Online: 28 April 2021

In-Text Citation: (Karim et al., 2021)

To Cite this Article: Karim, M. W., Haque, A., Ulfy, M. A., \& Hossin, M. S. (2021). Factors Influencing Student Satisfaction towards Distance Learning Apps During the Coronavirus (Covid-19) Pandemic in Malaysia. International Journal of Academic Research in Progressive Education and Development, 10(2), 245-260.

Copyright: (c) 2021 The Author(s)

Published by Human Resource Management Academic Research Society (www.hrmars.com)

This article is published under the Creative Commons Attribution (CC BY 4.0) license. Anyone may reproduce, distribute, translate and create derivative works of this article (for both commercial and non-commercial purposes), subject to full attribution to the original publication and authors. The full terms of this license may be seen

at: $\underline{\text { http://creativecommons.org/licences/by/4.0/legalcode }}$

Vol. 10(2) 2021, Pg. 245 - 260

http://hrmars.com/index.php/pages/detail/IJARPED

JOURNAL HOMEPAGE

Full Terms \& Conditions of access and use can be found at http://hrmars.com/index.php/pages/detail/publication-ethics 


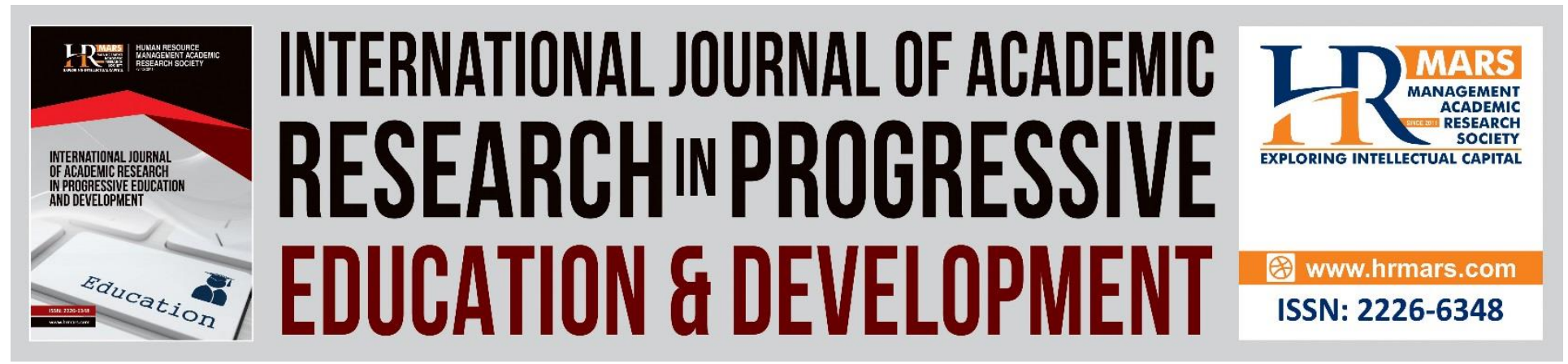

\title{
Factors Influencing Student Satisfaction towards Distance Learning Apps During the Coronavirus (Covid-19) Pandemic in Malaysia
}

\section{Md Wasiul Karim¹, Ahasanul Haque ${ }^{2}$, Mohammad Arije Ulfy ${ }^{3}$, Md Suliman Hossin 4}

M.Sc. in Marketing ${ }^{1,3}, \mathrm{PhD}$ in Marketing ${ }^{2}, \mathrm{PhD}$ in Management ${ }^{4}$, Department of Business Administration $^{1,2,3}$, UniKL Business School ${ }^{4}$, International Islamic University Malaysia ${ }^{1,2,3}$,

University Kuala Lumpur ${ }^{4}$

Email: md.suliman@s.unikl.edu.my ${ }^{4}$

\begin{abstract}
The latest coronavirus epidemic has witnessed a catastrophic fall in traditional education system and a significant change to app-based learning to maintain learning continuity. The conventional face-to-face teaching approach has been drastically altered with the addition of a new dimension in which student satisfaction is paramount. This current research paradigm is based on the TAM model. Students residing in Klang Valley, Malaysia, obtained a total of 483 data. By deploying SPSS and AMOS version 24.0, the study found self-efficacy as one of the deciding factors of student satisfaction; there is a strong correlation between self-efficacy and satisfaction. Furthermore, perceived usefulness and perceived ease of use are also influenced by self-efficacy. In contrast, perceived ease of use does not affect perceived usefulness, and perceived usefulness does not affect satisfaction. Finally, to increase the level of distance learning during COVID-19 outbreak, recommendations are made to enhance the virtual learning environment.
\end{abstract}

Keywords: AMOS, Covid-19, Distance Learning, Malaysia, Student Satisfaction, TAM.

\section{Introduction}

Student satisfaction has widely being studied but in distance learning environment it has generated concern due to its impact on the usefulness of teaching and instructional materials. Level of expectation and performance are the primary measurement of satisfaction but cultural differences affect the degree of satisfaction of students about their perception of the services provided (Tian \& Wang, 2010). Student satisfaction is an indicator of the quality of an educational program and is regarded as an important factor in the completion of the course (McQuillan, 2010). In most cases, students in postsecondary education programs end up leaving their studies because of unhappiness with their courses (Khan \& Iqbal, 2016). Satisfaction among students 
creates self-esteem that helps students build confidence, find additional skills and gain knowledge in a virtuous cycle. As we see in the world today, the COVID-19 pandemic is pushing academic institutions like universities to move very quickly to distance learning. We are already in a state of emergency and need to react with various and fully accessible learning methods, such as e-learning systems and virtual learning applications.

Studying student satisfaction in the form of distance learning has received attention due to its impact on the efficacy of teaching and educational materials. Distance learning on the other hand has gained popularity during the outbreak of Coronavirus (COVID-19) by shifting away from classroom to online learning in several areas of the globe (Li \& Lalani, 2020). Private universities and colleges in Malaysia no longer communicate students face to face and therefore have decided to switch to distance learning to arrest Covid-19 from spreading (Arumugam, 2020). With the implementation of the Movement Control Order (MCO), conventional exams are now replaced by other types of evaluation to maintain the social distance (Haque, Karim, Kabir, \& Tarofder, 2020). Distance learning tools in fact are playing a vital role during this pandemic. Distance learning systems can help learner control, schedule, execute and monitor the learning and teaching process. Microsoft Teams, Moodle, WhatsApp, Blackboard, Open Learning Network, WizIQ, Zoom, Facebook Livestream, Google Classrooms, Google Suites and Google Meet were amongst the industry's leading tools and innovations used by educators. Classes were usually performed according to existing timetables to ensure that a sense of "normality" survives, whereas alternative arrangements for evaluations were established.

Since the effectiveness of the distance learning system relies on the willingness and acceptance of the students to use this system, a lack of distance learning system use hinders the realization of benefits (Almaiah \& Alismaiel, 2019). Work on this subject is still in its infancy, where the students' viewpoints are not thoroughly investigated. Moreover, studying satisfaction among students regarding to use technology are in need. Studying adoption of distance learning will allow universities to understand the needs of their students better and ultimately lead to an effective distance learning program (El-Masri \& Tarhini, 2017). Although distance learning system has been implemented in various universities but thorough analysis on students satisfaction of using particular system is yet to be done during COVID-19 pandemic. Moreover, to perform the specific tasks, ability of using technology is indeed important for students. Additionally, confidence among students in terms of using technology can lead satisfaction. Although technology has widely being accepted in digital learning, students from different study fields are still unaware of using learning technology, thus dissatisfaction correlates. Online education can be efficacious in technologically advanced countries, but it is ineffective in developing countries like Malaysia due to self-efficacy (Adedoyin \& Soykan, 2020).

The primary objective of this study is to examine the satisfaction among students regarding to use distance learning application during the coronavirus pandemic in Malaysia. The specific objective of this study is to apply three variables technology self-efficacy, perceived usefulness and perceived ease of use to determine students' satisfaction towards distance learning apps. The remaining paper exhibits five sections including review of literature, research methods, results and findings, and limitations as well as future directions of research. 


\section{Literature Review}

Successful information systems are often being specified as a precursor of users' satisfaction (Almaiah, 2018). Thus, in distance learning system context, one of the main criteria for continuous success is students' acceptance. Several previous studies have identified an issue related to distance learning adoption in many countries of the world. Technology plays a vital role which assesses the level of satisfaction of students. By applying TAM Almaiah and Man (2016) critically evaluated the factors which affect the distance learning system. The result articulated the significant role of usability, responsibility, design and functionality which plays an important role to describe the conviction among Malaysian students. Almasri (2018) embeded TAM model to investigate the process of mobile learning among jordanian students. The result showed the significant association between perceived ease of use and individuals attitude (IA), perceived usefulness and IA and interaction and IA. Al-Azawei et al. (2017) investigated the diferencences and perceptions of an individual by deploying TAM model. The study also explored the relationship between technology adoption and satisfaction. Based on TAM3 Al-Gahtani (2016) found that, significant deteminants of technology-assisted learning system enhanced students towards acceptance. Baker et al. (2010) applied TAM 2 for cross-cultural evaluation of IT adoption. Findings from the study elicits the adoption of IT among Saudi Arabian organizations. Even though there are multiple studies on e-learning adoption, the present research aims to contribute in the existing literature on investigating the major obstacles and factors of students distance learning satisfaction in a modern context, which is Malaysia, which might also set an example for other underdeveloping nations.

\section{Technology Self-Efficacy (TSE)}

Self-efficacy is described as one's judgment about how well different courses of action can be carried out in various prospective circumstances with many unforeseeable and challenging elements (Bandura \& Schunk, 1981). The prior research concentrated more on the technical approach of self-efficacy in online learning, e.g. computer self-efficacy (Jan, 2015; Pellas, 2014; Wu, Tennyson, and Hsia, 2010), internet self-efficacy (Lin et al., 2013; Kuo et al., 2014), selfefficacy in the information seeking behavior (Tang \& Tseng, 2013) and learning management selfefficacy (Martin, Tutty, \& Su, 2010). In the process of learning, self-efficacy conveys evaluations of students on their cognitive capacity rather than affective to meet a particular learning mission or specific goals (Schunk, 1991). However, in the context of internet usage, it signifies the user's ability to perform or carry out the task required. According to Bhattacherjee (2002), the desire of consumers to use a technology is motivated by the satisfaction they have obtained from past experience while using the electronic system. Customer satisfaction was previously studied in the electronic banking context where Rusu and Shen (2012) described computer self-efficacy and convenience as two major factors driving customers to use the electronic banking platform. The introduction of self-efficacy as an essential form of motivation provides a deeper and clearer explanation of why as well as how the technology is being used (Ahmad et al., 2010) but to validate the extended technology acceptance model (ETAM) the study of Islam (2020) failed to produce a significant path-coefficient between computer self-efficacy and sastisfaction. The study futher needs to be rexamined during the outbreak of COVID-19. 
In terms of its effect on perceived ease of use (PEOU), computer self-efficacy (CSE) plays a critical role (Madorin \& Iwasiw, 1999). A meta-analysis conducted by Abdullah and Ward (2016) posited that, self-efficacy positively and significantly affects PEOU. Similarly, Chen (2012) found that usability of e-portfolios as a part of information technology (IT) are truly based on the ability of students. Different findings are documented regarding the relationship between SE and perceived usefulness (PU) literature. While several studies (Purnomo and Lee, 2013; Mohamed and Karim, 2012; Abbad, Morris and De Nahlik, 2009) have identified a lack of significant correlation between the SE and PU, some studies have found the positive association between SE and PU (Al-Ammary et al., 2014; Park, 2009; Al-Mushasha, 2013). Chen (2012) also found the positive and significant association between SE and perceived usefulness (PU). Based on the discussion above the proposed hypotheses are as follows:

$\mathrm{H1}$ : There is a positive association between TSE and Satisfaction.

$\mathrm{H} 2$ : There is a positive association between TSE and PU.

H3: There is a positive association between TSE and PEOU.

\section{Perceived Ease of Use (PEOU)}

Perceived ease of use (PEOU) is the degree to which a person is of the opinion that using a particular system would be effortless (Davis, 1989). It is hypothesized by Theory of Reasoned Action (TRA) that, behavioral actions are influenced by cognitive factors that can be assessed by predicting behavioral intentions. In addition, the Technology Acceptance Model (TAM) theorizes that the desire of individuals to use technology is measured by their perceived ease of use and perceived usefulness. Almarashdeh and Alsmadi (2016) postulated distance learning as a structured education program in Saudi Arabia where its usable modules are direclty influencing the usefulness of the system. Al-Azawei et al. (2017) examined the e-learning satisfaction and intention among Iraqi students, whereby, it describes the positive association between PEOU and PU. Sun et al (2008) have investigated design dimention as one of the six dimensions of an integreted model from which perceived ease of use found to have significant influence on elearners satisfaction. However, Al-Azawei et al (2017) also investigated an intregration model consists of satisfaction, where, PEOU found to have significant influence on satisfaction. But the study of Calli et al (2013) found that satisfaction among students regarding to use e-learning did not influenced by perceived ease of use. Al-hawari and Mouakket (2010) also failed to prove the contribution of PEOU on e-satisfaction. Nagy (2018) applied TAM to portray learning satisfaction through video demonstration. The result shows the usability of supplementary application enhance student towards use of the system, because students perceive that system will be useful only if usability is associated. Due to the COVID-19 outbreak, the situation regarding to adopt distance learning might have taken place as several countries have banned public gatherings (Owusu-Fordjour et al., 2020). It is suggesting to academicians to promote and imply online programs because of its easiness and usefulness (Wingo, Ivankova, \& Moss, 2017). With that abovementioned literature, the following hypotheses are formed:

$\mathrm{H} 4$ : There is a positive association between PEOU and PU.

$\mathrm{H} 5$ : There is a positive association between PEOU and satisfaction. 


\section{Perceived Usefulness (PU)}

Perceived usefulness is a degree to which a person perceives that the use of an information system will strengthen the efficiency of the task (Davis, 1989). In the context of e-learning system TAM has been widely adopted and examined the relationship between perceived usefulness and users' satisfaction. In this regard, Lee (2010) examined web-based learning system where, perceived usefulness of e-learning found one of the strongest determinant of students satisfaction. Alsabawy et al. (2013) postulate an integral method for controlling and implementing distance learning system, one of those are usefulness. The study also surveyed students persuing degrees in Australian university, result elicits perceived usefulness as strongest predictor of satisfaction and found significant relationship in between. Ibrahim et al. (2019) reveal the key elements of students satisfaction regarding to use technology for learning. Result highlighted that e-learning technology is beneficial and useful for higher educational institutions and students were satisfied using technology based learning system because of its effectiveness. Useful information system is crucial because it motivates users to engage with particular technology. Hence learning through technology has widely being adopted among university students and satisfaction perceived by them are truly based upon the quality or fact of being useful (Shah \& Attiq, 2016). Based on the discussion above, the following hypothesis is proposed: H6: There is a positive association between PU and satisfaction.

\section{Proposed Research Framework}

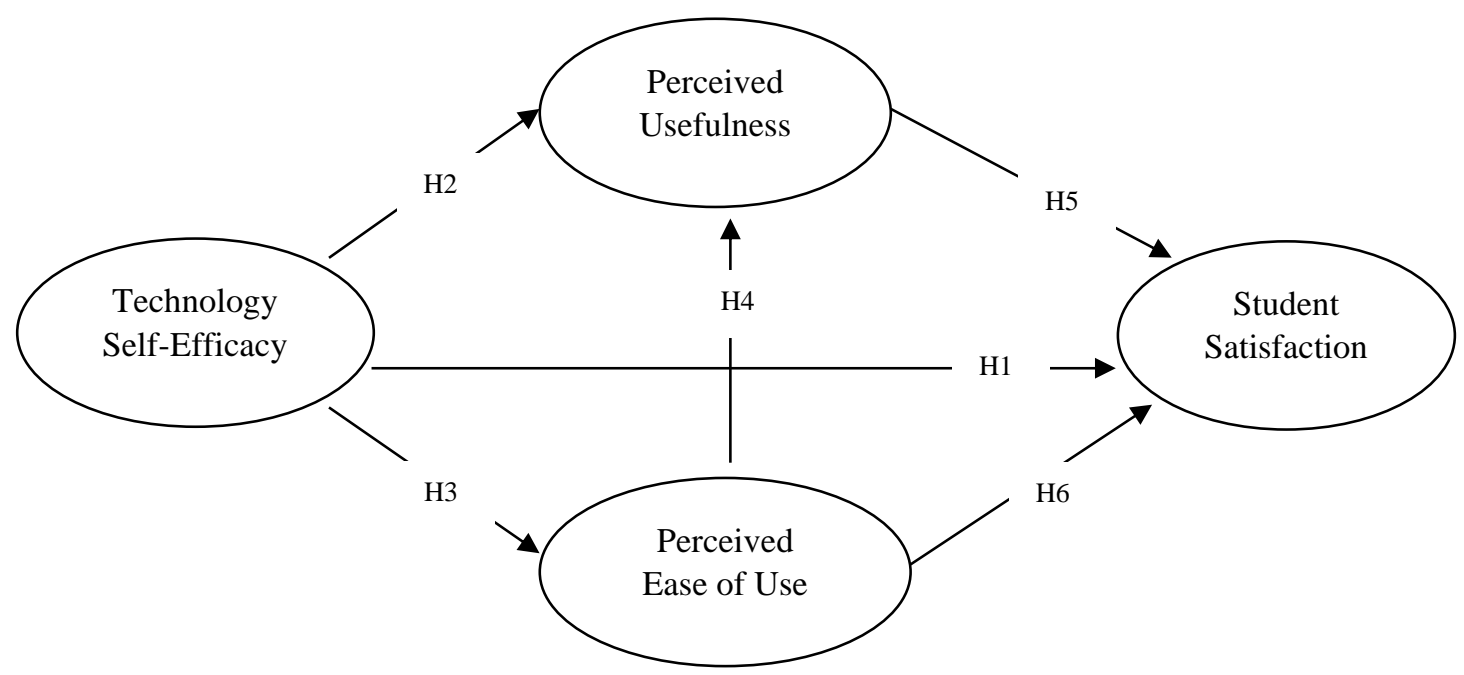

Figure 1: Conceptual Framework

\section{Research Methodology}

Construct Measurement

Current research include four constructs namely, technology self-efficacy, perceived usefulness, perceived ease of use and student satisfaction. Measurement items of all the constructs were mainly adopted from previous studies and then adapted to ensure that each element is suitable 
for the study. In this research, survey questionnaires were adopted primarily from Islam (2020) and Lee (2006). The first four items of technology self-efficacy and three items of student satisfaction were adapted from Islam (2020). Four items of perceived usefulness and perceived ease of use were adopted from Lee (2006). A total of 15 items from those four constructs were examined. To express the degree of acceptability, all measuring items were assessed using fivelikert scale ( 1 = strongly disagree to $5=$ strongly agree). Widely spoken language English was used to design the questionnaire. Last part of the questionnaire was designed to know the respondents age, gender, education and ethnicity.

\section{Data Collection}

The target population of this study was university students pursuing their degrees in Malaysia. Right after the movement control order (MCO) lifted researcher has selected Klang Valley for sample collection. Since the number of university students were infinite, total of 483 questionnaires were distributed with an aim to analyze atleast 385 as suggested by Glenn (1992).

$$
n_{0}=\frac{Z^{2} p q}{e^{2}}=\frac{(1.96)^{2}(.5)(.5)}{(.05)^{2}}=385 \text { Students }
$$

However, a total of 396 data found to be analyzable which represents $82 \%$ after screening and cleaning processes are accomplished. Data were obtained through social media sites and faceto-face distribution. The 396 respondents were surveyed for the study indicated a diverse demographic profile where male responded higher than female $(53 \%$ are male and $47 \%$ are female). Most of the respondents from Klang Valley are aged between 22 and 25 indicates 48.5\%, followed by the age between 26 and 30 (33.58\%). Respondents then were asked about their educational qualifications, found $58.83 \%$ of them were pursuing undergraduate degree. Lastly, $47.72 \%$ responses were from Malay ethnic group, followed by Chinese (25.76\%), Indian (17.93\%) and others (8.59\%).

\section{Result Analysis}

\section{Exploratory Factor Analysis (EFA)}

Exploratory Factor Analysis (EFA) is a statistical method for evaluating the association between variables in the dataset. Factor analysis is generally performed to reduce data. Large set of variables are taken to explore a way of how the data reduction can be useful to explain smaller set of factor or component. The Kaiser-Meyer-Olkin (KMO) test is usually performed for research purposes. The purpose of this study is to determine the degree of unidimensionality of the scales in the data collected. Total of 15-items of the four variables were factor analyzed. The KaiserMeyer-Olkin (KMO) and Bartlett test were carried out in order to validate adequate data for the purpose of factor analysis and the results are shown in Table 1.

Table 1: KMO and Bartlett's Test

\begin{tabular}{llr} 
Kaiser-Meyer-Olkin Measure of Sampling Adequacy. & .835 \\
Bartlett's Test of Sphericity & Approx. Chi-Square & 1650.633 \\
& df & 105 \\
& Sig. & .000 \\
\hline
\end{tabular}


For data purification, exploratory factor analysis was conducted using the key axis factoring and varimax rotation method. The varimax rotation technique is used to produce a matrix containing coefficients or loading factors representing the association of factors and variables. KMO and Bartlett indicate the higher values obtain from $\mathrm{KMO}$ and Bartlett is suitable enough for factor analysis. Four-factor solutions with a KMO statistic of 0.835 indicates that the sample size was adequate while further Bartlett's test of Sphericity was found significant at .000 and a chi-square statistic of 1650.633 with 105 degrees of freedom. The total variance in the five factors explained was 72.417. The Eigen value is commonly used to calculate the number of variables, and a cutoff value of 1 is typically used to identify factors that are dependent on eigenvalues. The eigenvalues for the four factors were $5.087,2.263,1.844$ and 1.667 respectively.

The findings suggest that the data were suitable for factor analysis. Things were aggregated resulting in the discovery of four main factors. For the purpose of the report, these four factors are identified with new names, which are Factor 1 as Technology self-efficacy, Factor 2 as Perceived Ease of User, Factor 3 as Perceived Usefulness and, finally, Factor 4 as Satisfaction. The study then used Cronbach's alpha for further reliability test calculation. Using SPSS, the alpha value of 0.892 for Technology self-efficacy (4 items), 0.809 for Perceived Usefulness (4 items), 0.864 for Perceived Ease of Use (4 items) and 0.854 for student satisfaction ( 3 items) were calculated which explains that all the items in the scale used to measure the variables taking part are reliable. Cronbach's alpha should have 0.7 or higher than that are recommended by Pallant (2007).

\section{Confirmatory Factor Analysis (CFA)}

A multivariate statistical method is called Confirmatory Factor Analysis (CFA) which has been used to determine how well the number of constructrs are represented by measured variables. The proposed framework for measurements (Figure 2) was therefore tested using AMOS.

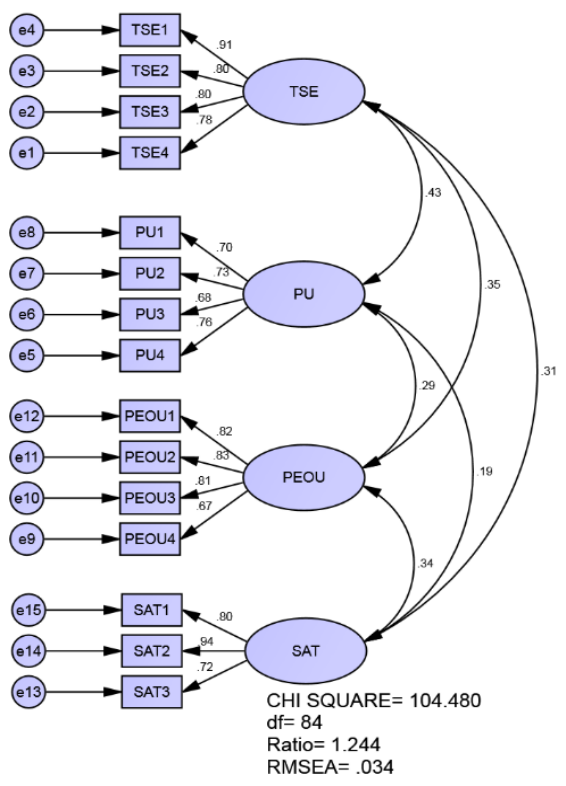

Figure 2: Measurement Model 
Vol. 10, No. 2, 2021, E-ISSN: 2226-6348 @ 2021 HRMARS

CFA was performed to evaluate the factor structure that consists of a 15-item scale using AMOS. The association of four latent constructs has been presumed. Based on the modification indices presented by AMOS, no indicatores were eliminated from the measurement model as loadings of each items were found to be 0.7 and above. Hair et al. (2010) signified any loading value below 0.5 will be considered insignificant. To ensure a good model fit, Table 1 displays nine good fit model indices. According to Hair et al. (2010), the value of GFI and CFI are suggested to be more than 0.95 and RMSEA should be smaller than 0.05 in order to clarify well fit. For $\times 2 / d f$, below 3 was considered good value and acceptable. TLI should at least be 0.90 or above than that value.

Table 2: Model Fit

\begin{tabular}{lllllllll}
\hline$x^{2}$ & $\mathrm{df}$ & $\mathrm{x} 2 / \mathrm{df}$ & $\mathrm{GFI}$ & $\mathrm{RMSEA}$ & $\mathrm{NFI}$ & $\mathrm{CFI}$ & $\mathrm{IFI}$ & $\mathrm{TLI}$ \\
\hline 104.480 & 84 & 1.244 & 0.942 & 0.034 & 0.938 & 0.987 & 0.987 & 0.984 \\
\hline
\end{tabular}

The 15-item scale shows the good model fit and acceptable as the minimum thresholds concerted.

In order to achieve good composite reliability, it was suggested that the minimum agreed value be 0.7 as recommended by Chin (1988). In addition, the average extracted variance (AVE) value should be at least 0.5 or even more, as suggested by Hair et al. (2006). Present study was calculated AVE to prove good indication. Standardized loadings of each item were used to calculate AVE where, sum of the squared standardized loadings were divided by the number of indicators. AVE found to be ranging from 0.516 to 0.681 which was greater than a minimum threshold of 0.5 . Study also explained CR value ranging from 0.810 to 0.965 that exceeded the ideal threshold value of 0.7 . Therefore, in order to maintain discriminatory validity, it is important to prove that the measures which should not be related are not actually related (Hair et al., 2013). Discriminating validity can also be measured by the square root of AVE (Fornell \& Larcker, 1981). Table 3 shows the high discriminant validity as it demonstrates that the square AVE of each factor exceeds all its correlations with the other factors.

$$
\begin{aligned}
& A V E=\frac{\sum \lambda_{i}^{2}}{\sum \lambda_{i}^{2}+\sum_{i} \operatorname{Var}\left(\varepsilon_{i}\right)} \\
& C R=\frac{\left(\sum \lambda_{i}\right)^{2}}{\left(\sum \lambda_{i}\right)^{2}+\sum_{i} \operatorname{Var}\left(\varepsilon_{i}\right)}
\end{aligned}
$$

Table 3: Confirmation Factor Analysis (CFA) Report

\begin{tabular}{lcccccc}
\hline \multicolumn{1}{c}{ Variables } & AVE & CR & TSE & PU & PEOU & SAT \\
\hline Technology Self-Efficacy (TSE) & 0.679 & 0.965 & $\mathbf{0 . 8 2 4}$ & & & \\
Perceived Usefulness (PU) & 0.516 & 0.810 & 0.430 & $\mathbf{0 . 7 1 8}$ & & \\
Perceived Ease of Use (PEOU) & 0.617 & 0.865 & 0.351 & 0.288 & $\mathbf{0 . 7 8 5}$ & \\
Satisfaction (SAT) & 0.681 & 0.863 & 0.311 & 0.189 & 0.336 & $\mathbf{0 . 8 2 5}$ \\
\hline
\end{tabular}

Note: $A V E=$ Average variance extracted, $C R=$ Composite reliability 


\section{Structural Model}

The six (6) hypotheses were examined in this research to look at the causal pathways. The results of hypothesis testing are described in Table 4 on the basis of the hypothesized structural model. Among the six tested hypotheses, four are statistically significant $(p<0.05)$ and the remaining two failed to be significant. $R^{2}$ value was evaluated. Technology self-efficacy accounted for $12.4 \%$ of variance $\left(R^{2}=0.124\right)$ in explaining perceived ease of use and $20.6 \%$ of variance $\left(R^{2}=0.206\right)$ in explaining perceived usefulness. Meanwhile, Technology self-efficacy, perceived ease of use and perceived usefulness were accounted for $15.6 \%$ of the variance $\left(R^{2}=0.156\right)$ in explaining student satisfaction towards distance learning apps.

The results of hypotheses $\mathrm{H} 1$ signify that a positive association between technology self-efficacy and student satisfaction is supported based on $\beta=0.211 ; \mathrm{SE}=0.078 ; \mathrm{CR}=2.491$. Similarly $\mathrm{H} 2$ and $\mathrm{H} 3$ were supported based on the $\beta$ value which shows 0.375 for $\mathrm{H} 2$ and 0.351 for $\mathrm{H} 3$ respectively. $\mathrm{H} 2$ also shows the $\mathrm{SE}=0.060 ; \mathrm{CR}=4.371$ and significant $\mathrm{P}$ value which indicated that technology self-efficacy have positive and significant influence on perceived usefulness. Similar result can be seen for $\mathrm{H} 3$ where $\mathrm{SE}=0.057$; $\mathrm{CR}=4.424$ thus, $\mathrm{H} 3$ was also supported by explaining that there is a positive relationship between technology self-efficacy and perceived ease of use. On the other hand, $\mathrm{H} 4$ shows that there was no significant relationship is associated between perceived ease of use and perceived usefulness. With the value of $\beta=0.156 ; \mathrm{SE}=0.080$ and $C R=1.909$ and $p$ value was higher than 0.05 the hypothesis $(\mathrm{H} 4)$ was not supported. $\mathrm{H} 5$ found to be significant based on the $p$ value $(p<0.05)$ which indicates a positive relationship between perceived ease of use and satisfaction. $\mathrm{H} 6$ which express that no positive relationship is associated between perceived usefulness and student satisfaction. Thus, result of $\mathrm{H} 6$ is rejected based on $\beta=0.025 ; \mathrm{SE}=0.111$ and $\mathrm{CR}=0.289$.

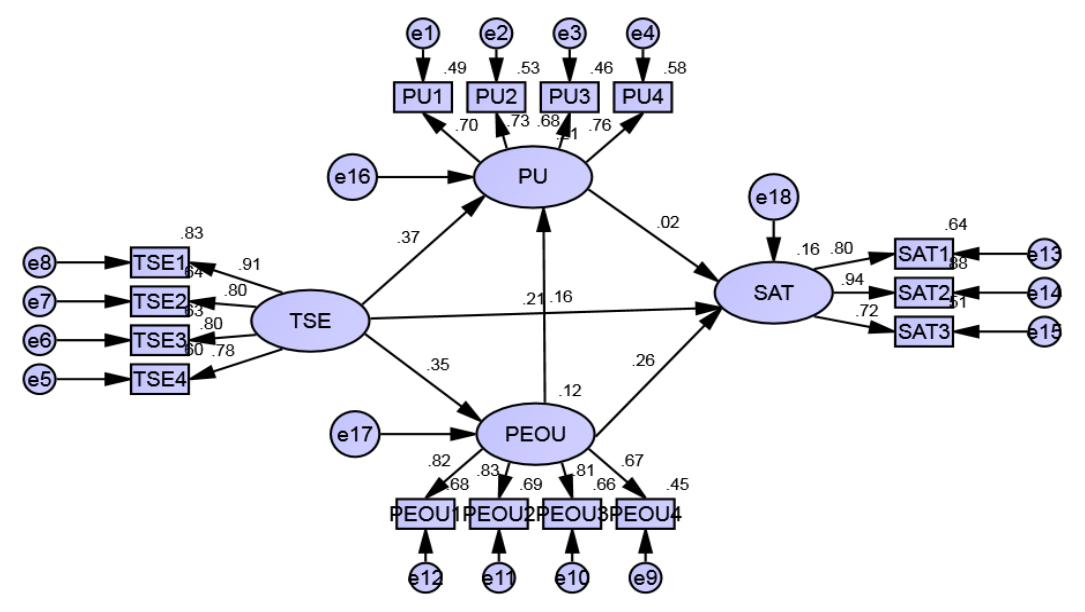

Figure 3: Structural Model 


\section{Discussion}

The findings of this study reveal that technology self-efficacy is an important factor among university students during COVID-19 pandemic. In terms of distance learning satisfaction student have perceived how well he/she can afford in paying attention to online learning since the number of educational institutions are shifting from face-to-face instruction to online based learning. Current study has successfully proved the effectiveness of technology and knowledge regarding to use it (H1 was supported). Although Islam (2020) failed to signifiy the postive relationship between technology self-efficacy and satisfaction, current study found that without technologial sense distance learning is not satisfactory. Similarly, perceived technological sense among students are necessary for understanding the effectiveness of distance learning. Current study found the positive association between technology self-efficacy and perceived usefulness. Thus, H2 is in line with the prior study of Chen (2012). Consequently, if the technology is perceived by students as useful, simple and easy, they will eager to accept it (Abdullah \& Ward, 2016). The study then investigated the relationship between PEOU and PU. Although online learning in previous studies have found to be convenient and easy,current study failed to explain the significant relationship with Perceived usefulness. Although several studies have interpreted the technology based learning system to be useful if students perceived that it is clear and understandable (Lee, 2006; Shah and Attiq, 2016), current reseach found that during the COVID19 outbreak students satisfaction towards distance learning systems are based on how easy and accessible the designed system rather than its effectiveness. Hence, perceived ease of technology use for distance learning doesn't influencing its usefulness and therefore ended up by rejecting H4.

Study findings suggest that perceived ease of use have huge effects on student satisfaction (H5 was supported). From the findings it can be concluded that easy to use distance learning programs are of vital importance for student satisfaction during COVID-19. Result of this study is consistent with the prior research of Islam (2020). To validate the extended TAM model both satisfaction and self-efficacy were meta analyzed where perceived ease of use found to be important factor in determining satisfaction among students. In addition, students have been asked to do social distance, saying that all educational institutions should encourage online learning and teachers should be encouraged to use the systems in a much easier way. On the contrary, perceived usefulness of distance learning apps found to have no significant impact on student satisfaction. Student perceived that learning through technology is satisfactory if the system is easy to operate rather than its evvectiveness. This is because those who were not very proficient in online learning due to the corona virus, they want this system to make it easier for them. Thus $\mathrm{H} 6$ is not supported. 
Vol. 10, No. 2, 2021, E-ISSN: 2226-6348 @ 2021 HRMARS

Table 4: Hypotheses Testing

\begin{tabular}{|c|c|c|c|c|c|c|}
\hline$H$ & Relationship & $\operatorname{SRW}(\beta)$ & S.E. & C.R. & $p$-value & Decision \\
\hline $\mathrm{H} 1$ & $\mathrm{SAT} \leftarrow \mathrm{TSE}$ & 0.211 & 0.078 & 2.491 & 0.013 & Supported \\
\hline $\mathrm{H} 2$ & $\mathrm{PU} \leftarrow \mathrm{TSE}$ & 0.375 & 0.060 & 4.371 & $* * *$ & Supported \\
\hline H3 & PEOU $\leftarrow$ TSE & 0.351 & 0.057 & 4.424 & $* * *$ & Supported \\
\hline $\mathrm{H} 4$ & $\mathrm{PU} \leftarrow \mathrm{PEOU}$ & 0.156 & 0.080 & 1.909 & 0.056 & Not Supported \\
\hline H5 & $\mathrm{SAT} \leftarrow \mathrm{PEOU}$ & 0.255 & 0.105 & 3.110 & 0.002 & Supported \\
\hline H6 & $\mathrm{SAT} \leftarrow \mathrm{PU}$ & 0.025 & 0.111 & 0.289 & 0.772 & Not Supported \\
\hline
\end{tabular}

Note: ${ }^{*} \mathrm{p}<0.05 ;{ }^{* *} \mathrm{p}<0.01 ;{ }^{* * *} \mathrm{p}<0.001$

\section{Contributions and Implications}

This study provides quantitative insights into the latest trend and an understanding of students' distance learning satisfaction during the novel Coronavirus COVID-19. In addition, the results of this study suggest the reliability and validity of the Technology Acceptance Model in the assessment of student satisfaction and its relationship with the preceding variables. To support the theory, current study has employed perceived usefulness and perceived ease of use to direct the relationship with satisfaction. In TAM model perceived ease of use and usefulness was hypothesized as important precursors to predict the behavioral intention. Current work is also an important addition to TAM by proposing a model to resolve an antecedents of perceived usefulness and perceived ease of use. In the online learning environment, technology knowledge is mandatory. On account of this, technology self-efficacy was designated as an external factor of TAM model.

The results of this study give Malaysian education sector a few managerial implications. Firstly, the findings of this study will allow the educational institution 's authority to better understand the best strategy for the education sector to be enforced. In addition, app developers can take important steps to make their apps easier for students to use. Because the findings of this study reveal that Satisfactory attitude of students depends on the ease of use of these distance learning apps because the easier the apps are to use, the more motivated the students will be to use them. Currently, a number of educational institutions in Malaysia have shifted from face-to-face classes to online classes for Covid-19, as a result of which all kinds of activities are being performed online. Online classes have not been very well conducted in Malaysia before, so students can be a little hesitant about the proper use of this technology in education. For this, developers should consider how to make apps easier for students.

\section{Limitations and Future Research}

This study has few limitations. First, due to time constraints, researchers have only given much priority to the Klang Valley area in Malaysia, where university students living in that particular area are preferred. Since this research has adopted a convenient sampling technique and selected the Klang Valley Zone, there are many potential candidates for data collection who are outside the Klang Valley Area and have been excluded from the survey. Second, even though the movement control order (MCO) was lifted by imposing Standard Operating Procedure (SOP) in Malaysia due to the numbers of Covid-19 cases were dropped, some students could not 
participate in the survey due to security reasons, which resulted in the exclusion of a significant portion of the participants. However, it is further recommended that future study could cover throughout the Malaysia including Sabah and Sarawak as the numbers of students in that particular area are not low. Convenient sampling method has widely being applied by researchers to generalize the results but also it has been criticized by many researchers as well. Future research could adopt simple random sampling method so the likelihood for selection for each member of the subset is equal.

\section{Reference}

Adedoyin, O. B., \& Soykan, E. (2020). Covid-19 pandemic and online learning: the challenges and opportunities. Interactive Learning Environments, 1-13.

Abbad, M. M., Morris, D., \& De Nahlik, C. (2009). Looking under the bonnet: Factors affecting student adoption of e-learning systems in Jordan. International Review of Research in Open and Distributed Learning, 10(2), 1-26.

Abdullah, F., \& Ward, R. (2016). Developing a General Extended Technology Acceptance Model for E-Learning (GETAMEL) by analysing commonly used external factors. Computers in Human Behavior, 56, 238-256.

Ahmad, T., Madarsha, K., Zainuddin, A., Ismail, N., \& Nordin, M. (2010). Faculty's acceptance of computer based technology: Cross-validation of an extended model. Australasian journal of educational technology, 26(2), 268-279.

Al-Ammary, J. H., Al-Sherooqi, A. K., \& Al-Sherooqi, H. K. (2014). The acceptance of social networking as a learning tools at University of Bahrain. International Journal of Information and Education Technology, 4(2), 208-214.

Al-Azawei, A., Parslow, P., \& Lundqvist, K. (2017). Investigating the effect of learning styles in a blended e-learning system: An extension of the technology acceptance model (TAM). Australasian Journal of Educational Technology, 33(2), 1-23.

Al-Gahtani, S. S. (2016). Empirical investigation of e-learning acceptance and assimilation: A structural equation model. Applied Computing and Informatics, 12(1), 27-50.

Al-hawari, M. A., \& Mouakket, S. (2010). The influence of technology acceptance model (TAM) factors on students'e-satisfaction and e-retention within the context of UAE e-learning. Education, Business and Society: Contemporary Middle Eastern Issues, 3(4), 299-314.

Almaiah, M. A. (2018). Acceptance and usage of a mobile information system services in University of Jordan. Education and Information Technologies, 23(5), 1873-1895.

Almaiah, M. A., \& Alismaiel, O. A. (2019). Examination of factors influencing the use of mobile learning system: An empirical study. Education and Information Technologies, 24(1), 885-909.

Almaiah, M. A., \& Man, M. (2016). Empirical investigation to explore factors that achieve high quality of mobile learning system based on students' perspectives. Engineering science and technology, an international journal, 19(3), 1314-1320.

Almarashdeh, I., \& Alsmadi, M. (2016). Investigating the acceptance of technology in distance learning program. 2016 International Conference on Information Science and Communications Technologies (ICISCT) (pp. 1-5). IEEE. 
INTERNATIONAL JOURNAL OF ACADEMIC RESEARCH IN PROGRESSIVE EDUCATION AND

DEVELOPMENT

Vol. 10, No. 2, 2021, E-ISSN: 2226-6348 @ 2021 HRMARS

Almasri, A. (2018). New mobile learning process model for higher education students in Jordanian universities. International Journal of Information, Business and Management, 10(1), 201-213.

Al-Mushasha, N. F. (2013). Determinants of e-learning acceptance in higher education environment based on extended technology acceptance model. 2013 Fourth International Conference on e-Learning" Best Practices in Management, Design and Development of e-Courses: Standards of Excellence and Creativity" (pp. 261-266). IEEE.

Alsabawy, A. Y., Cater-Steel, A., \& Soar, J. (2013). IT infrastructure services as a requirement for e-learning system success. Computers \& Education, 69, 431-451.

Arumugam, T. (2020). Covid19: Education sector grapple with technology, virtual, online classrooms. Retrieved June 22, 2020, from New Straits Times:

https://www.nst.com.my/news/nation/2020/04/585687/covid19-education-sectorgrapple-technology-virtual-online-classrooms

Baker, E. W., Al-Gahtani, S. S., \& Hubona, G. S. (2010). Cultural impacts on acceptance and adoption of information technology in a developing country. Journal of Global Information Management (JGIM), 18(3), 35-58.

Bandura, A., \& Schunk, D. H. (1981). Cultivating competence, self-efficacy, and intrinsic interest through proximal self-motivation. Journal of personality and social psychology, 41(3), 586-598.

Calli, L., Balcikanli, C., Calli, F., Cebeci, H. I., \& Seymen, O. F. (2013). Identifying Factors That Contribute to the Satisfaction of Students in E-Learning. Turkish Online Journal of Distance Education, 14(1), 85-101.

Chen, M. Y., Mou-Te Chang, F., Chen, C. C., Huang, M. J., \& Chen, J. W. (2012). Why do individuals use e-portfolios? Journal of Educational Technology \& Society, 15(4), 114125.

Chin, W. W. (1988). The partial least squares approach to structural equation modeling. Modern methods for business research, 295(2), 295-336.

Davis , F. D. (1989). Perceived usefulness, perceived ease of use, and user acceptance of information technology. MIS Quarterly, 13(3), 319-340.

El-Masri, M., \& Tarhini, A. (2017). Factors affecting the adoption of e-learning systems in Qatar and USA: Extending the Unified Theory of Acceptance and Use of Technology 2 (UTAUT2). Educational Technology Research and Development, 65(3), 743-763.

Fornell, C., \& Larcker, D. F. (1981). Evaluating structural equation models with unobservable variables and measurement error. Journal of marketing research, 18(1), 39-50.

Glenn, D. I. (1992). Determining Sample Size. Tarleton State University.

Hair , J. F., Black, W. C., Babin , B. J., Anderson , R. E., \& Tatham, R. L. (2006). Multivariate data analysis (Vol. 6). Pearson Prentice Hall: Englewood Cliff, NJ.

Hair, J. F., Anderson, R. E., Babin, B. J., \& Black, W. C. (2010). Multivariate data analysis: A global perspective. Pearson Upper Saddle River: NJ: Person Prentice Hall.

Hair, J. F., Ringle, C. M., \& Sarstedt, M. (2013). Partial least squares structural equation modeling: Rigorous applications, better results and higher acceptance. Long range planning, 46(1-2), 1-12. 
INTERNATIONAL JOURNAL OF ACADEMIC RESEARCH IN PROGRESSIVE EDUCATION AND

DEVELOPMENT

Vol. 10, No. 2, 2021, E-ISSN: 2226-6348 @ 2021 HRMARS

Haque, A., Karim, W., Kabir, S. H., \& Tarofder, A. K. (2020). Understanding Social Distancing Intention among University Students during Covid-19 Outbreak: An Application of Protection Motivation Theory. TEST Engineering and Management, 83, 16360-16377.

Ibrahim, N. B., Ibrahim, N. S., Zukri, S. M., Yusof, M. M., \& Roslan, N. N. (2019). Learners satisfaction of e-learning among public university students: a case study in Kota Bharu. Journal of Mathematics \& Computing Science, 5(1), 1-7.

Islam, A. (2020). Viability of the extended technology acceptance model: An empirical study. Journal of Information and Communication Technology, 10, 85-98.

Jan, S. K. (2015). The relationships between academic self-efficacy, computer self-efficacy, prior experience, and satisfaction with online learning. American Journal of Distance Education, 29(1), 30-40.

Khan, J., \& Iqbal, M. J. (2016). Relationship between student satisfaction and academic achievement in distance education: a Case Study of AIOU Islamabad. FWU Journal of Social Sciences, 10(2), 137-145.

Kuo, Y. C., Walker, A. E., Belland, B. R., Schroder, K. E., \& Kuo, Y. T. (2014). A case study of integrating Interwise: Interaction, internet self-efficacy, and satisfaction in synchronous online learning environments. International Review of Research in Open and Distributed Learning, 15(1), 161-181.

Lee, M. C. (2010). Explaining and predicting users' continuance intention toward e-learning: An extension of the expectation-confirmation model. Computers \& Education, 54(2), 506516.

Lee, Y. C. (2006). An empirical investigation into factors influencing the adoption of an elearning system. Online information review, 30(5), 1468-4527.

Li, C., \& Lalani, F. (2020, April 29). The COVID-19 pandemic has changed education forever. This is how. Retrieved June 2020, 22, from World Economic Forum:

https://www.weforum.org/agenda/2020/04/coronavirus-education-global-covid19online-digital-learning/

Lin, Y. C., Liang, J. C., Yang, C. J., \& Tsai, C. C. (2013). Exploring middle-aged and older adults' sources of Internet self-efficacy: A case study. Computers in Human Behavior, 29(6), 2733-2743.

Madorin, S., \& Iwasiw, C. (1999). The effects of computer-assisted instruction on the selfefficacy of baccalaureate nursing students. Journal of nursing education, 38(6), 282-285.

Martin, F., Tutty, J. I., \& Su, Y. (2010). Influence of Learning Management Systems Self-Efficacy on E-Learning Performance. Journal on School Educational Technology, 5(3), 26-35.

McQuillan, D. J. (2010). Massage therapy education online: student satisfaction and achievement, part I. International Journal of Therapeutic Massage \& Bodywork, 3(2), 313.

Mohamed, N., \& Karim, N. (2012). Open Source E-learning Anxiety, Self-Efficacy and Acceptance-A Partial Least Square Approach. International Journal of Mathematics and Computers in Simulation, 6(4), 361-368.

Nagy, J. T. (2018). Evaluation of online video usage and learning satisfaction: An extension of the technology acceptance model. International Review of Research in Open and Distributed Learning, 19(1), 161-185. 
INTERNATIONAL JOURNAL OF ACADEMIC RESEARCH IN PROGRESSIVE EDUCATION AND

DEVELOPMENT

Vol. 10, No. 2, 2021, E-ISSN: 2226-6348 @ 2021 HRMARS

Owusu-Fordjour, C., Koomson, C. K., \& Hanson, D. (2020). The impact of Covid-19 on learningthe perspective of the Ghanaian student. European Journal of Education Studies, 7(3), 88-101.

Park, S. Y. (2009). An analysis of the technology acceptance model in understanding university students' behavioral intention to use e-learning. Journal of Educational Technology \& Society, 12(3), 150-162.

Pellas, N. (2014). The influence of computer self-efficacy, metacognitive self-regulation and selfesteem on student engagement in online learning programs: Evidence from the virtual world of Second Life. Computers in Human Behavior, 35, 157-170.

Purnomo, S. H., \& Lee, Y. H. (2013). E-learning adoption in the banking workplace in Indonesia: an empirical study. Information Development, 29(2), 138-153.

Rusu, R. F., \& Shen, K. N. (2012). An empirical study on e-banking acceptance in the United Arab Emirates (UAE). Journal of Electronic Banking Systems, 20(2), 1-10.

Schunk, D. H. (1991). Self-efficacy and academic motivation. Educational psychologist, 26(3-4), 207-231.

Shah, H. J., \& Attiq, S. (2016). Impact of technology quality, perceived ease of use and perceived usefulness in the formation of consumer's satisfaction in the context of e-learning. Abasyn Journal of Social Sciences, 9(1), 124-140.

Sun, P. C., Tsai, R. J., Finger, G., Chen, Y. Y., \& Yeh, D. (2008). What drives a successful eLearning? An empirical investigation of the critical factors influencing learner satisfaction. Computers \& education, 50(4), 1183-1202.

Tang, Y., \& Tseng, H. W. (2013). Distance learners' self-efficacy and information literacy skills. The journal of academic librarianship, 39(6), 517-521.

Tian, R. G., \& Wang, C. H. (2010). Cross-cultural customer satisfaction at a Chinese restaurant: The implications to China foodservice marketing. International Journal of China Marketing, 1(1), 60-72.

Wingo, N. P., Ivankova, N. V., \& Moss, J. A. (2017). Faculty perceptions about teaching online: Exploring the literature using the technology acceptance model as an organizing framework. Online Learning, 21(1), 15-35.

Wu, J. H., Tennyson, R. D., \& Hsia, T. L. (2010). A study of student satisfaction in a blended elearning system environment. Computers \& Education, 55(1), 155-164. 